\title{
ЕП О ГИЛГАМЕШУ У СВЕТЛУ НАСТАВНОГ ПРОУЧАВАЊА
}

\section{САЖЕТАК}

Рад представља наставно тумачење старог сумерско-акадског епа са становишта његове организације, карактеризације јунака епа, ситуирање божанстава у епски ток приповедања. Посебна пажња посвећена је феномену сна, опису борбе и борбених противника, Гилгамешове потраге за бесмртношћу, као и опису потопа и силаска Гилгамеша у подземни свет.

КЉУЧНЕ РЕЧИ: еп, епски јунак, епска божанства, бесмртност, потоп, сан, путовање, наставно тумачење. 
K ада је године 1849. Остен Хенри Лејерд откопао

Сенахерибову палату у Ниниви, у рушевинама је крај ње пронашао библиотеку цара Асурбанипала и затекао мноштво текстова исписаних клинастим писмом. ${ }^{1)}$ Ту су се налазили делови приче о Гилгамешу, које је 1872. Џорџ Смит успео да дешифрује. Асурбанипал, асирски краљ, био је веома суров владар, али и префињени библиофил и велики љубитељ уметности. Он је на подручју Месопотамије основао најпознатију библиотеку (7. в. п. н. е.), познату као Асурбанипалова библиотека. ${ }^{2)}$ Пронађена је у рушевинама, седам метара испод земље. Ова библиотека имала је преко 22.000 глинених таблица, око 20.000 књига. ${ }^{3)}$

Оваква корелација са археолошким открићими може се ученицима учинити као ваљана мотивација за рад на самом тексту, нарочито ако се у неком методичком кораку представи у интермедијалној презентацији, као делотворни принцип очигледности. Са овим епом сусрећу се већ на самом почетку средњошколског образовања када је немогуће спојити дијахронијски начин предочавања књижевноисторијског стваралаштва са принципом поступности и ситематичности којим би дела из старине требало да изучавају у зрелијим годинама. Зато је потребно увести их у епски свет антике поступно и потпуније, пре него што почну да читају само дело. Прича о најстаријој цивилизацији води на тло Месопотамије где су настајале сумерска, ${ }^{4)}$ акадска, гутијска, вавилонска и асирска култура. Даљина ових цивилизација ученицма може бити несхватљива, но приче о вавилонској кули, Семирамидиним вртовима и другим занимљивостима требало би да привуче њихову пажњу.

1) Свака плоча била је сигнирана редним бројем серије и имала је утиснут

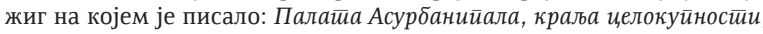
краља Асирије. Садржала је, дакле целокупно знање оног времена из разних наука и уметности које је краљ наручио. Већином су то преписи раније вавилонске књижевности. Клинасто писмо било је познато и раније. Сматра се старијим писмом од египатских хијероглифа (Препрек 1985: 13)

2) Касније су пронађена и друга налазишта са глиненим плочама. Значајно је налазиште код Нипура које је било 1500 година старије од Асурбанипалове библиотеке. У њему је нађен крај епа о Гилгамешу.

3) Данас се плоче чувају у Британском музеју у Лондону.

4) Сумерци, који су себе називали Кенги индоевропског су порекла, досељени на то подручје у петом миленијуму, док су остали народи семитског порекла. Сумерска култура сматра се најстаријом, а њихово писмо најстарије је познато писмо (Препрек 1985: 17-18).

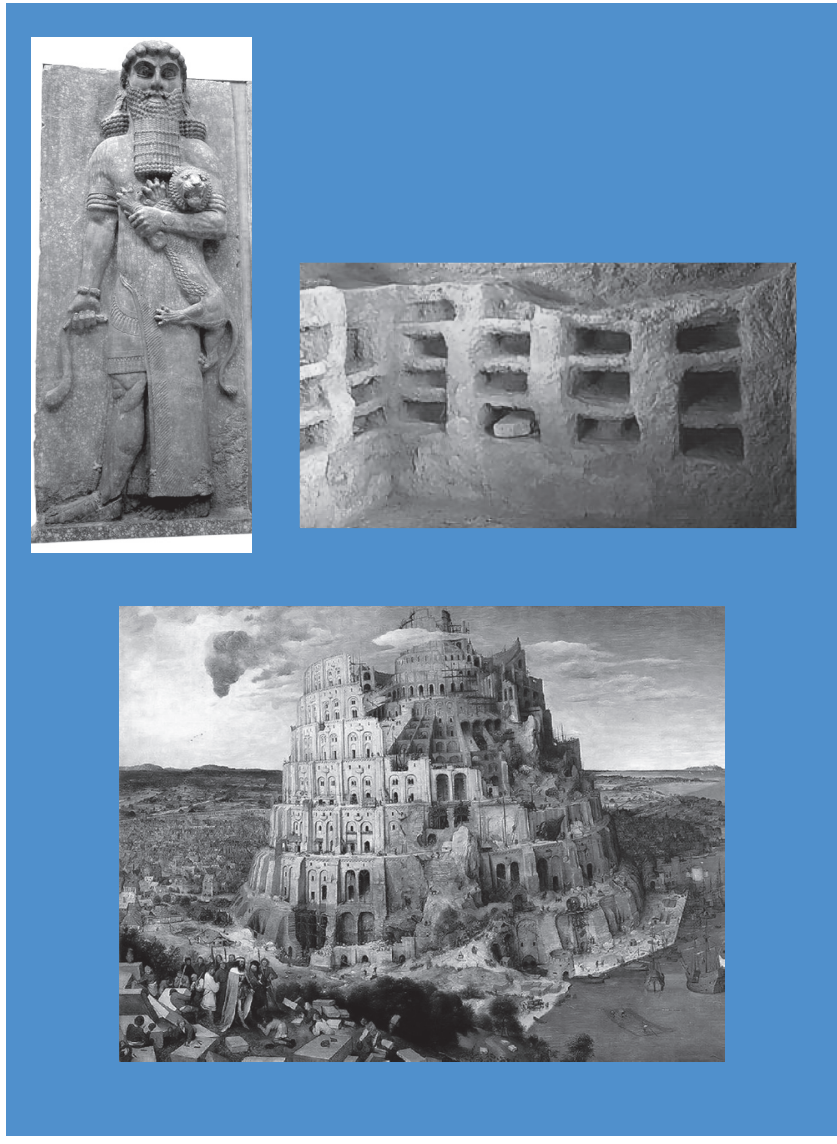

Један од запажених владара био је Хамураби (17921750. п. н. е), владар династије старог Вавилона (врата господња). ${ }^{5)}$ Његово име везујемо за Хамурабијев законик, до скора сматран првим правним писаним робовласничким закоником у историји. ${ }^{6)}$ Написан је на базалтном стубу од $225 \mathrm{~cm} .{ }^{7)}$ Вавилон, највећи антички град, био је опасан троструким бедемом ширине до седам метара. Вавилонска кула, зигурат Етеменанки (кућа камена темељца неба и земље), била је висока деведесет и један метар, са темељима ширине деведесет

5) Вавилон се налази стотинак километара јужно од Багдада. Изградили су га Сумерци, а први пут се помиње у 23. веку пре нове ере.

6) Николић сматра да да су закони које је Хамураби написао заправо преписани, блажи, закони практиковани још код Сумераца (Николић 1990: 14)

7) Данас се чува у Лувру. 
метара. Имала је седам спратова, све ужих према врху. Последњи висок петнаест метара, био је посвећен богу Мардуку, украшен модрим и златними плочицма. Висећи вртови краљице Семирамиде спадали су у седам чуда старог света. Овако развијена култура несумњиво је дала и значајна књижевноуметничка дела. Књижевност је представљала спој уметности, филозофије и религије заједно. Жанровски најпопуларнији били су епови као: Енума елиш, еп о постанку света, Ишйарин

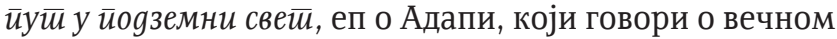
животу, еп о уручком краљу Гилі̄амешу ${ }^{8)}$ и дуги.

Претходне методичке радње могу се обавити на више начина у зависности од времена које ћемо одвојити за интерпретацију ове теме:

- ученицима се корелацијски показује монолошком методом припремљена презентација

- ученицима дајемо могућност да на интернету сами пронађу податке о одређеним артефактима

Пре читања, свакако ћемо усмерити ученике одређеним радним захтевима који ће им касније помоћи у интерпретацији дела. Већ по обиму припремних задатака види се да се економичност може постићи групним радом, но у фази припремања за аналитички рад, фази разговора о непосредном доживљавању уметничког дела, наставни процес би требало поставити фронтално.

\section{Припремни задаци:}

1. Приликом читања епа обрати пажњу на организацију догађаја.

2. Попиши стихове који казују какви су јунаци били Гилгамеш и Енкиду.

3. Одреди и запиши богове који се именују у епу са њиховим делокругом моћи.

4. Покушај да одгонетнеш шта у епу представљају снови.

5. Како су представљене борбе јунака? Пробај да их редом забележиш.

6. Еп чине описи и нарација, но већина текста припада дијалошкој форми. Са ким све Гилгамеш разговара почев од осме плоче?

8) Мисли се да је Гилгамеш и библијска личност по дименом Нимрод која се помиње у Књизи постања (X 8, 9, 10) (Препрек 1985: 11).
7. Одреди топографију (поља, брда, градови) која се помиње у епу и повежи их са датим догађајима.

Интерпретацију дела отпочињемо формалним одредницама да бисмо поставили основне постулате и методе даљег наставног рада. Прво ћемо се позабавити локализацијом епа у геопоетичком обзорју.

\section{Како настаје еп о уручком краљу Гилгамешу?}

Еп о Гилгамешу настајао је током дужег периода. Протекло је шест хиљада година до данашњих дана откако се Гилгамеш упустио у прометејску авантуру потраге за бесмртношћу. Предање је најпре било усмено. Циклус легенди о Гилгамешу настаје најпре на сумерском, а најстарије верзије на вавилонском језику настале су око 18. веку п. н. е. и садрже основне делове приче. ${ }^{9)}$ Сматра се да је еп као целина састављен око 1700. године п. н. е.

Данашњи облик епа представљен је на дванаест глинених плоча, да ли случајно тако сложених или не, но број плоча одговара броју стихова у експозиционом делу прве плоче који почиње одом, похвалом уручком краљу. Фронталним радом отворићемо проучавање епа питањима везаним за његову организацију да бисмо поставили темеље проучавања и избегли препричавање:

- Еп садржи дванаест плоча. Може ли се поделити на два дела? Покушај да нађеш разлоге оваквој глобалној подели, ако се прича сведе на путовања.

- Можеш ли да одредиш експозицију и објасниш је?

Еп се може поделити на два, готово једнака, дела, ако се ослонимо на догађаје представљене као путовања у буквалном и пренесеном значењу, (путовање - живот). У првом делу представљено је јуначко путовање Гилгамеша и Енкидуа и њихове борбе са епским непријатељима - фантастичним чудовиштима, Хумбабом и небеским биком. Мелетински наводи да је одлика ране форме јуначког епа, или архаичног, како га назива, бајковито јунаштво јунака-делија који поседују страст

9) Еп је познат у неколико варијаната у којима се и јунаци другачије именују, но свим варијантама су заједнички исти садржаји, догађања: Гилгамешово пријатељство са Енкидуом, Њихова заједничка борба са Хумбабом и небеским биком, Утнапиштимова прича о великом потопу и Гилгамешов пут у подземни свет (Препрек 1985: 39). 
ратника и херојску тврдоглавост у епским борбама са фантастичним непријатељима (Мелетински 2009: 95). Догађаји се износе са ведрином и борбеношћу. У другом делу, после смрти пријатеља Енкидуа, као моменту раздвајања епске приче, Гилгамеш, осетивши ненадокнадиви губитак, тугује и јадикује док путује у потрази за Утнапиштимом и травом бесмртности. У йрвом gелу ойисан је Гилітамешов о онос иррема сииољњем светиу, а у gруїом њет̄ов оgнос иррема себи самом (Препрек 1985: 43).

Експозициони део почиње похвалом владара који је две трећине бог, а трећином човек. Оно почетно све указује на епски свет, схваћен као јединствена целина, на чијем врху се, у јасној хијерархији, налази краљ, господар земље. Он је све вияео, каже се, јер је као ју- нак упознао сву суштину и мудрост живота која је дата смртнику. Пошто је градио град Урук, деспотски се односио према својим поданицим и није их пуштао својим женама, својим кућама. То је први хибрис, јогунство Гилгамешово и прекорачење моћи смртника. Богови му стварају будућег пријатеља од блата, удвајају јунаке да би поравнали њихове земаљске моћи.

Поделом ученика на групе, према дидактичким захтевима такве поделе, интерпретација ће биће усмерена према основним смерницама већ наглашеним у припремним задацима.

Прва група имаће задатак да представи лик Гилгамеша и Енкидуа уз помоћ цитата које су сами издвојили, или уз сугестије наставника.

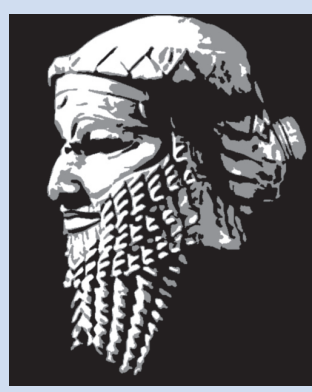

- Једна трећина је човек, а две трећине бог

- Грађани га гледају са дивљењем и страхом

- Нема му равног по лепоти и снази

- Његова реч и говор у граду су закон

- Гилгамеш - човек бола и радости

- Тело му је пуно укроћене снаге, није уморан

- Он је као дивљи бик

- Огрнут је кожом лава

г Пастир који штити народ

- Човек страха и потраге за травом живота
- Направљен од блата и пљувачке богиње (обликовања) Аруру и оживљен крвљу и дахом бога (борбеног) Ниниба на захтев Ануа (неба)

- Дуге је таласаве косе као пшеница, ништа не зна о свету и људима, огрнут крзном као Сумукан (бог њива и стада) (човек поља и слободе)

- Снажан потомак неба ("војска је била као један човек"

- Иницијација Енкидуова: преко жене (угледа је и баци на земљу, шест дана и седам ноћи) и борбе (са најјачим: Гилгамешом)

- Жена га кити сјајним оделом и поји вином и хлебом (увођење у свет цивилизације)

- Пантер степе

- Брз као газела 


\section{Да се подсетиш:}

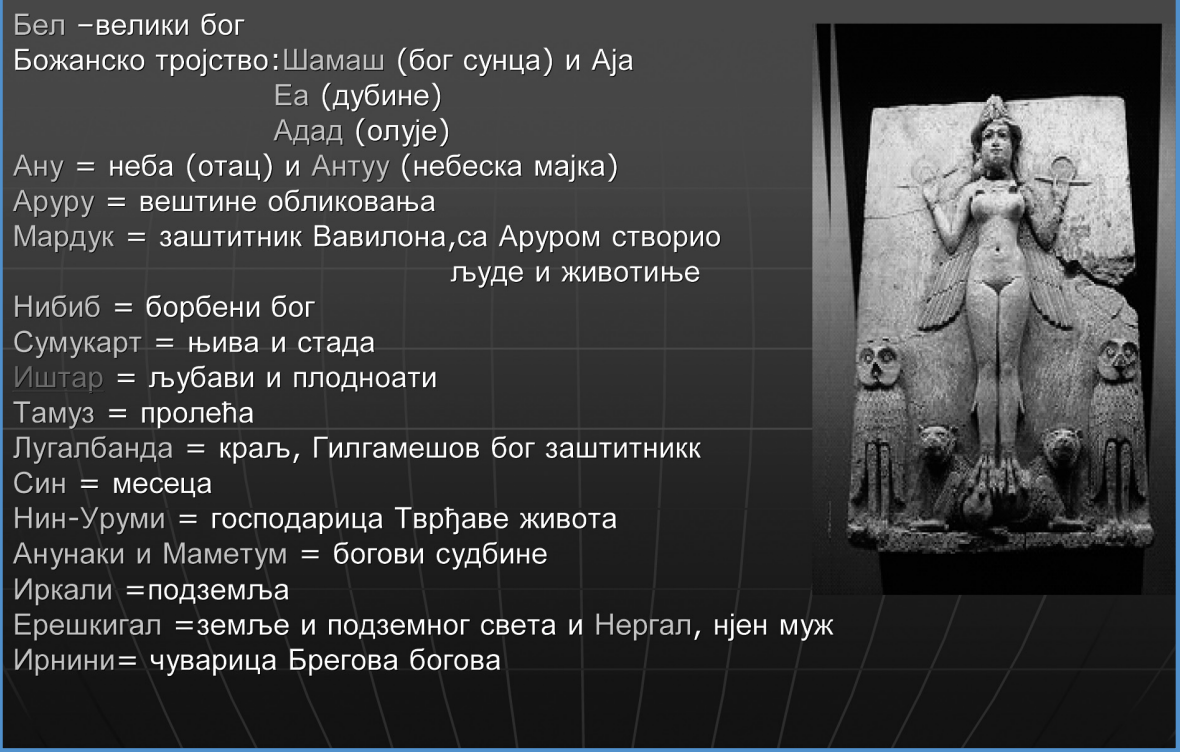

Ученицима неће бити тешко да увиде да су ова два јунака два антипода. Гилгамеш је културни јунак високе формације, градитељ који стреми изједначавању са боговима, док је Енкиду човек степе, стваран од блата, који временом губи своју природну дивљину и природну невиност. (Мелетински 2009: 105-106). Увођењем Енкидуа у градски живот цивилизације, а без слободе (животиње се отуђиле од њега), Гилгамеш добија пријатеља и саборца у авантурама у које се упуштају. Свака цртица на слајду захтева јасну експликацију и локализовање у тексту.

Следећи задатак увешће сумерске богове у наставну интерпретацију. Задатак за ученике је да саопште на који начин богови учествују у радњи епа. Ради лакшег сналажења и уштеде у времену, наставник би требало да припреми попис божанстава са њиховим делокругом моћи, јер то представља репрезентативни део проучавања и има функцију лакшег сналажења у тексту. Могу се ученицима дати и бројеви страница на којима се поједина божанства појављују, уколико сматрамо да је задатак превише захтеван. То може да се представи графиконом.

Када је Гилгамеш у жељи да цивилизује живот и подигне град подредио сав народ и претворио их у робове који га покорно слушају, јадиковке народа чуо је бог неба Ану и нареди Аруру да створи још једног јунака да Гилгамеш не буде сам и највећи. Аруру ствара својим соковима Енкидуа из блата којему Нибиб додаје мушку борбеност. Света жена из Иштариног храма уводи га у свет цивилизације. Ову жену, Иштарину следбеницу, Енкиду ће проклињати јер је због ње изгубио исконску природност. На исти начин ће Гилга- 
меш одбити Иштар, богињу плодности, спочитавајући јој промискуитет и несталност, сметнувши с ума да је она богиња плодности. ${ }^{10)}$ Богињи Иштар, која је представљена на слици у презентацијском материјалу, поклања се највише места у епу и њена је улога, чини се, значајнија од осталих божанстава у вези са догађањима у самој причи. Гилгамеш ће неколико пута прекорачити меру која је дата човеку и узнемирити богове. Иако га је божанско тројство изабрало за владара и подарило му памет, снагу и мудрост, често бива горд и пркосан боговима. Одбијајући Иштар, богињу плодности, одбио је ритуално саједињавање за добробит и свога народа. ${ }^{11)}$ Одбијање Иштарине наклоности имало је високу цену по народ. Она, расрђена, уцењује ${ }^{12)}$ небеског оца Ануа, да пусти чаробног бика који носи седам година зла, глади и болести на људе. Гилгамеш је миљеник бога Шамаша, те му он помаже да убије небеског бика. И тиме је упао у још један хибрис, заједно са Енкидуом. Да ли је Енкидуова смрт имала везе са овим моментом, место је за разматрање, као и то колико је Гилгамеш због своје гордости човек бола и радости. Нису ли тиме скренули пажњу Ерешкигал да их упише у своје књиге мртвих? Богови су живели на Брегу богова где је обитавао Ану, бог неба. Када је Иштар рђаво саветовала богове да потопи људе, а велики бог Бел послао потоп, Еа је спасао Утнапиштима саветом да направи лађу. Од несагледивих последица и разорне моћи потопа и сами богови уплашили су се своје одлуке. ${ }^{13)}$ Ученици ће закључити да су богови

10) Марко Вишић у богињи Иштар види блудницу, осветољубиву особу, оличење зла које пушта Небеског бика да сатре људски род (Вишић 2003 147). Она је ипак богиња љубави и плодности и у читавом епу нема ни једног женског лика који јој не служи, чак и краљева мајка њена је следбеница.

11) Пребацујући Иштари љубавну несталност, Гилгамеш је одбија јер неће да дели судбину других које је изневерила: Моју љубав желищ/ а йосйуйаћеш са мном као и са њима. Иштар то види овако: Оче на небу, Гилїамеш ме је ирроклео/ он ми је као зла набројао сва моја gела / Посйуйио је са мном срамойно.

12) Сам небески отац Ану види своју кћер као моћну жену која је у стању

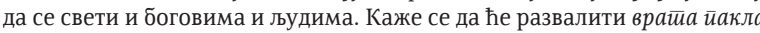
и пустити све ђаволе из Подземља, као и све мртве (превод Станислава Препрека). Заиста велика моћ. Доњи свет је место где живе сенке, дакле сви умрли. Овај део је проблематичан у разумевању, но говори о ванредним Иштариним моћима.

13) И сами се бог̄ови уйлашише йот̄ойа/ ...Шћућурени као йси йураху се међу собом/...Ишишар виче као жена у иеешком йорођају/... Како сам само мо-

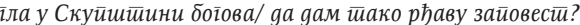

представљени у човеколичју са свим особинама људским, са изузетком што су бесмртност за себе оставили, а човеку је ускратили. Они су активни делатници у епском догађању.

Задатак за ученике који ће тумачити функцију снова у епу може бити олакшан следећим радним захтевима:

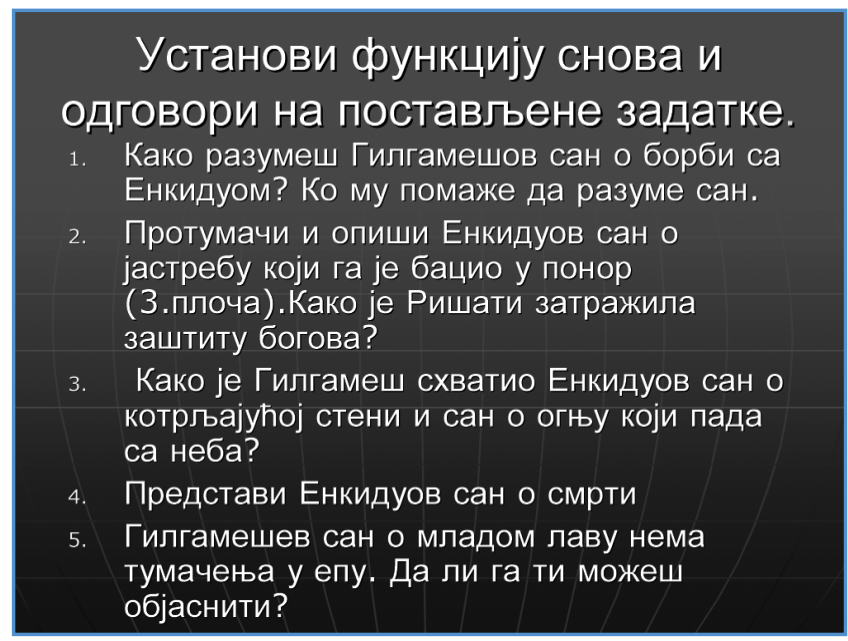

Сан је јасно и формулативно дат у тексту епа као предсказање онога што у животима јунака наилази. Његова формулативност садржи, прво, испричан сан, а затим неко од јунака (мајка или сам Гилгамеш) тумачи тај сан. Ученицима је радним задацима усмерена пажња на пет снова које ће лако пронаћи у тексту и о којима ће моћи да говоре. Већ у првој плочи налази се Гилгамешов сан којим се јасно назначује да ће из ритуалне борбе са Енкидуом, која је више као иницијаца у цивилизовани живот, него супарничка борба, Гилгамеш пронаћи пријатеља и побратима. То му саопштава његова мајка, висока свештеница. У другом сну Енкиду наслућује своју судбину од које се брани ритуалним жртвовањем злослутном судији Утукиу (да протера седморо злих) и поклања бодеж, зделу од црвеног камена, пуну меда и другу, од лапислазура, испуњену маслацем. Сан говори о јастребу који га баца у јаму загробног живота, где људи попут птица огрнути перјем пребивају у тами. Ерешкигал је спазила Енкидуа и његова смрт је извесна. Свештеница и мајка молила је богуњу Ају и њеног љубавника, бога Шама- 
ша, да штите Гилгамеша. На исти начин она моли и Енкидуа да га штити, тако он постаје нека врста Гилгамешовог заточника смрти, испрва, замењена жртва. Два пута Енкиду сања сан који је Гилгамеш тумачио као добро знамење, да ће убити чудовиште Хумбабу. У њој човек постаје прах и то је мотив који на различите начине говори о смрти као претећој и пратећој сили у читавом епу, која их покреће и гони на путовање. Но, сан о орлу који узвисује Енкидуа и баца га у понор, на земљу, јесте предсказање његове смрти. Закључују да се суgбина не може заустиавити и да су му богови gоcyguли несрећу (Гилгамеш 1985: 84). Након дванаест дана болести Енкиду умире. Гилгамеша приказују као човека који у руци држи младог лава. Његов последњи сан представљен је у лову на младог лава којег је хтео да убије док се играо и радовао животу. Стрела са неба разбила је земљу и он је упао у њу. Симболика је јасна, нарочито када се сан локализује у тексту. Гилгамеш се упустио у авантуру потраге за вечним животом, но неће га досегнути и слутећи то, скамењен је од страха пред смрћу свога пријатеља и побратима.

Да се јунаци гледају и по својим противницима, опште је место. Ученицима дајемо задатке који ће осветлити одважност и јуначка дела Гилгамеша и Енкидуа по начину на који су представљени њихови противници. У нашој народној епици Марко Краљевић представља јунака који се бори са сличним непријатељима, што ученицима није нимало страно.

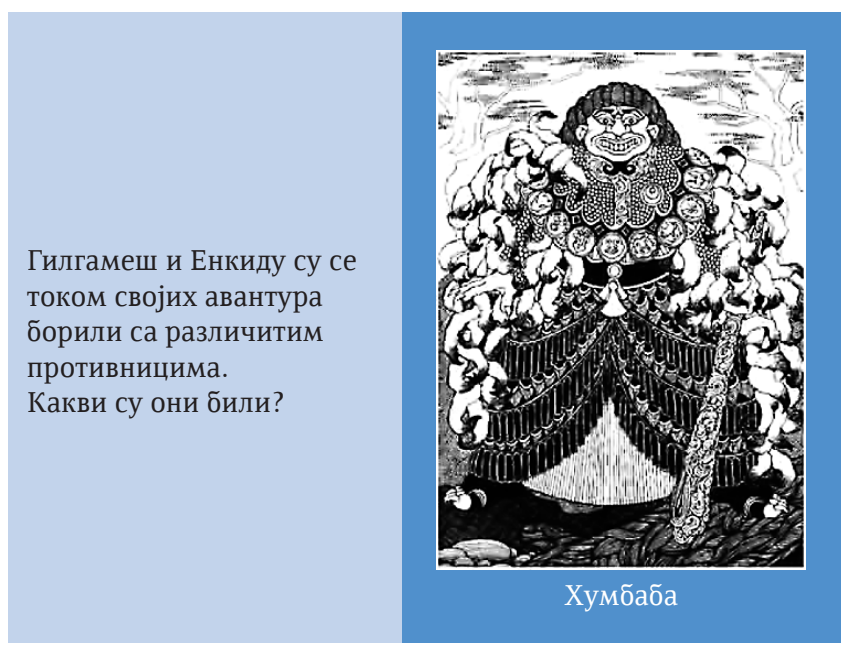

Уочљиво је да су сви јунаци противници били натприродна бића са ванредном снагом и посебним моћима. То свакако доприноси јуначкој неустрашивости, великој снази и неизмерној одважности двојице хероја који су се таквим створењима супротставили. Пошто је сваки од њих поседовао надљудске моћи, сасвим је очекивано да су их два побратима савладала уз помоћ бога заштитника, Шамаша, и неких других њима наклоњених божанстава. Први је био Хумбабин чувар шуме, заоденут у седам чаробних огртача. Други, велики чувар кедрове шуме, Хумбаба, чудовиште које је Бел поставио за чувара, одважио се преко мере и никога није пуштао до Капије сунца, те је тиме увредио Шамаша, бога сунца и судију богова и људи. Тело му је било љускава бронза, шапе лава, а канџе јастреба, на глави рогови као у бика, а реп и уд са главама змија. Трећи беше небески бик, његово ватрено дахтање уништавало је стотине људи. Три пута су покушали да га улове и тек су му трећи пут зарили, тореадорски, мач у груди и откинули уд, што им Иштар није опростила. Пратила их је њена клетва.

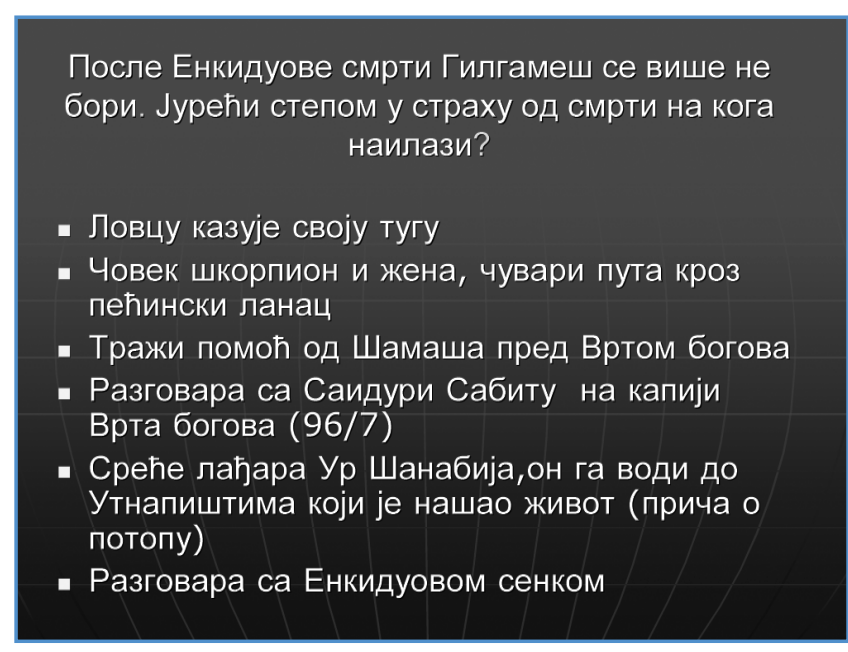

Јурећи од смрти у жељи да га не стигне љуgска суgбина, Гилгамеш доживљава разне авантуре. Сваку

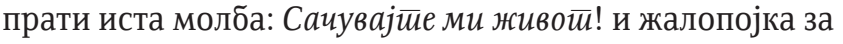
Енкидуом, која се у епском понављању и у дијалогу са различитим сабеседницима, своди на тугу и страх од смрти која га непрекидно гони. Путовање је потрага за 
травком бесмртности без предаха и одмора. Путовање у сусрет боговима отвара митска места античког света као општа места свеукупне литературе са којима ће се ученици сусретати проучавајући културну потку књижевноуметничких дела светске баштине. Дакако да су по важности представе о потопу и силазак у адски свет посебно интересантни. Упознаће ученици касније библијски потоп, начине на који су Одисеј, Орфеј и други силазили у адска предворја и пространства, сусрешће се са феноменом змијског лукавства у причи о одузимању вечног живота. Гилгамешово путовање ка светлости, Капији сунца, пут је кроз мрачан пећински ланац и тамну непроходну шуму. Симболика пута, шуме, светлости показује им се по први пут. Сусрећу се са античком представом о свету сачињеном тако да га два дива држе на плећима, главе су им на небу, а доњи део, у облику шкорпијиног репа, силази у подземни свет сенки. Они чувају капију која кроз пећински ланац води до Сунчеве капије, где на ушћу вода, иза Вода смрти станује Утнапиштим, једини човек којем су богови подарили вечни живот и спасли га од великог потопа. Стигао је Гилгамеш до њега и нашао траву живота и у жељи да се коначно одмори, да је не поједе сам, већ прометејски подели својему племену. Одахнуо је непажљив, те га је змија преварила и украла му травку. Гилгамеша је ипак стигла људска судбина. И ту се отвара питање о смислу човековог трајања које Сабиту, богиња Стабла живота, овако представља: Зайо јеgu u йuj, Гилі̄амешу,/

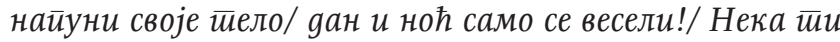
је сваки gан раяосна свешиковина! (Гилгамеш 1985: 97). Утнапиштим, човек вечности казаће то овако: Човеку није о оређен вечан живой.../ Ойкако су gани заиочели, нишита није йрајно./ Не личе ли јеgно gруі̄ом/ новорођено gейе и смрй? (Гилгамеш 1985: 105).

\section{Топографија епа}

- Опис града и његовог живота

- Опис степе, Ануових брегова

- Кедрова шума и Брег богова

- Планина Машу, Сунчева капија и пећински ланац

- Светско море, Воде смрти и Острво живота

- Капије Подземља

Завршне одредбе у раду на овом епу могу, опет, да се обаве као део групног рада, или фронтално, или као писмени домаћи рад, али би било интересантно обавити овај задатак у корелацији са другим уметностима.

\section{Л И Т Е Р А У Р А}

- Гилїамеш, сумерско-бабилонски ей (1985). Превео и приредио Станислав Препрек. Сарајево: Веселин Маслеша.

- Вишић, Марко (2003). Сумерско-акаgски ей о Гилїамешу. Поговор. Превео и приредио Марко Вишић. Београд: Драганић.

- Мелетински, Јелеазар М. (2009). Увоg у исйоријску йоетику ей и романа. Београд: Књижевна мисао.

- Николић, Никола; Николић, Сергије (1990).

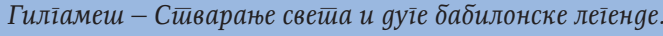
Загреб: Отворено свеучилиште.

- Препрек, Станислав (1985). На трагу ране културе. Гилїамеш, сумерско-бабилонски ей.

Сарајево: Веселин Маслеша. 
Branka M. Jakšić Provči

\section{EPIC OF GILGAMESH FROM THE} EDUCATIONAL POINT OF VIEW

\section{Summary}

The paper presents an educational interpretation of the old Sumerian and Acadian epic considering its organization, the characterization of its main protaginists, and the positioning the gods within the narrative flow of the epic. Special attention is given to the phenomenon of sleep, the description of fights and fighting rivals, Gilgamesh's quest for immortality, as well as to the description of flood, and Gilgamesh's descend into the underworld.

Key words: epic, epic hero, epic gods, immortality, flood, dream, journey, educational interpretation. 